\title{
Solos cariocas: subjetividade e políticas da cena
}

\author{
José Da Costa
}

I

$\gamma$

$m$ dos traços bastante comuns entre os espetáculos teatrais solos que tenho em mente ao escrever esse texto é a atuação predominantemente frontal em relação ao público, ou seja, a remessa direta dos discursos proferidos em cena aos espectadores. ${ }^{1}$ Em O Autofalante, ${ }^{2}$ Pedro Cardoso se dirige aos espectadores, no início do espetáculo, para uma espécie de prólogo, no qual ele afirma que demorou muito para conseguir construir um desfecho para a peça. Acrescenta que o desfecho a que chegou e que finalmente o deixou satisfeito, guarda, entretanto, certa estranheza. É que, conforme o encerramento concebido pelo artista para seu espetáculo, com o desaparecimento da personagem, irá desaparecer também o ator, que não voltará para os agradecimentos fi- nais. Em tom de leve gracejo, o artista, então, pede licença aos espectadores para "adiantar um serviço e agradecer logo agora”. Depois disso, o comediante faz o gesto de se curvar em agradecimento e o público aplaude antecipadamente com sorrisos de satisfação em relação ao primeiro momento da noite teatral, momento que propiciou um contato percebido como direto (não mediado por um personagem ficcional) entre o comediante e os espectadores.

Meus companheiros de platéia na noite em que fui ao teatro são, ao que tudo indica, pessoas de classe média alta e mediana, que puderam pagar o ingresso e assistir ao espetáculo de Pedro Cardoso, em um teatro localizado no interior de um Shoping Center, no bairro elegante da Gávea, zona sul do Rio de Janeiro. ${ }^{3}$ Com a concessão de seus aplausos e sorrisos prévios, os espectadores demonstram que entenderam e

José Da Costa é professor do Departamento de Teoria do Teatro e do Programa de Pós-Graduação em Teatro da Unirio.

1 Estarei discutindo aqui espetáculos solos produzidos e apresentados no Rio de Janeiro nos anos de 2006 e 2007. Alguns desses trabalhos, porém, são retomadas de criações exibidas vários anos antes, como é o caso de $O$ autofalante de Pedro Cardoso, ou são mostrados ao longo de um tempo considerável, como $O$ pregoeiro de Marcio Libar, que começa a apresentar o seu solo em 2001.

2 O espetáculo tem direção de Amir Haddad e Pedro Cardoso, enquanto o texto dramatúrgico foi escrito pelo ator.

3 Assisti o espetáculo na temporada do Teatro das Artes, Rio de Janeiro, julho de 2007. 
aceitaram a proposta de relação pessoal e quase íntima que o artista lhes apresenta em sua performance inicial, construída para expressar absoluta informalidade e desprendimento.

No momento inicial da peça, ratifica-se, a cada apresentação, o pacto de adesão ao campo do conhecido e do familiar. Esse é o território preferencial, se não único, das relações que se estabelecerão entre o ator e o público de classe média que, então, o assiste no teatro. Público esse que parece querer ratificar o mesmo e o já sabido, reencontrando ao vivo o artista de televisão, especialmente querido, sem dúvida, em decorrência de sua sensibilidade de comediante, marcada por um registro de fragilidade e timidez. Assim, a estranheza do final que leva Pedro Cardoso a falar diretamente ao público no início do espetáculo é um gancho falso, uma vez que aquilo que a menção ao estranhável introduz é, de certo modo, um pacto de exclusão do estranho e do não familiar.

Ocorre, porém, que o próprio artista não cumpre inteiramente o pacto proposto. $\mathrm{Na}$ estrutura dramatúrgica, na organização visual do espetáculo (o palco vazio e as imagens esgarçadas do espaço urbano projetadas ao fundo $)^{4} \mathrm{e}$ no modo de tratar os temas abordados (a ruptura da subjetividade, a dor, a solidão e o desamparo), há certos fatores de tensionamento em relação à expectativa habitual do receptor (a exemplo de uma temporalidade complexa e de um radical despojamento cênico). Mas de qualquer modo, a facilidade e a rapidez com que os contratantes-espectadores aderem ao pacto proposto inicialmente demonstram a sua predisposição na direção precisa do acordo de fidelidade ao esperado.
A atuação de Ana Kfouri, em $O$ animal do tempo, texto do dramaturgo francês contemporâneo Valère Novarina, também é predominantemente frontal. ${ }^{5}$ Há, entretanto, desde o início do espetáculo indícios de uma disposição reticente e reservada em relação à expectativa de proximidade e pessoalidade que o solo teatral provoca no espectador. A peça originalmente se apresentou para um público pequeno, de aproximadamente 40 espectadores por sessão. A sala em que estreou o trabalho não tem palco. $\mathrm{O}$ espectador se encontra na mesma altura da atriz que, no início do espetáculo, está, porém, a uma distância significativa. Em uma das pontas do retângulo - que a organização cenográfico-espacial estabeleceu para nele conter a relação da atriz com os espectadores - encontra-se o local reservado para o pequeno público da peça. $\mathrm{Na}$ outra extremidade, ao fundo da sala, na perspectiva da platéia, a atriz toca acordeão enquanto os espectadores entram e se dirigem a suas cadeiras. A sensação de profundidade e distanciamento é intensificada pela iluminação e por certa faixa de obscuridade (que é mantida, em grande trecho do espetáculo), entre o local em que se encontra a atriz e aquele em que estão os espectadores. ${ }^{6}$

Após a acomodação do público nas cadeiras a ele destinadas, Ana Kfouri, ainda toca seu acordeão. Só depois de transcorrido algum tempo, começa a utilizar a voz, não com uma linguagem verbal articulada, mas cantarolando uma melodia que acompanha ao instrumento. A atriz ainda está no fundo da sala e não se dirige aos espectadores de modo direto e explícito. Não se delineia tampouco um universo ficcional fechado, que necessite da convenção da quarta

4 Os vídeos são criados por Marcelo Tass.

5 O espetáculo, com direção de Antônio Guedes, estreou na Sala Multi-uso do SESC-Copacabacana (Rio de Janeiro, agosto/2007), tendo feito uma temporada posterior no Teatro do Jóquei (outubro2007). O texto de Valère Novarina foi traduzido por Ângela Leite Lopes. Assisti, ao espetáculo, inicialmente, no SESC-Copacabana. Agradeço à atriz a cessão do vídeo da peça.

6 A iluminação é de Wilson Reis. 
parede separando-o inteiramente do público. $\mathrm{O}$ discurso que a atriz enuncia é dirigido de modo ambíguo, em parte para os espectadores presentes, em parte para qualquer ouvinte, para o mundo, para ninguém em particular. $\mathrm{O}$ fato de não se estabelecer um tom de conversa cotidiana entre camaradas ou amigos faz com que a frontalidade da fala ganhe um caráter distinto do que me parece que se verifica no início de $O$ autofalante.

$\mathrm{O}$ sujeito que fala em $O$ animal do tempo é um personagem solitário, aparentemente frágil e marginal, que se encontra em um cemitério, lendo inscriçôes nas lápides tumulares e tecendo comentários e conjecturas aleatórias enquanto as lê. A personagem de Pedro Cardoso é também um sujeito solitário. Desempregado, sem família e sem posses, é vítima de um surto esquizofrênico em que se defrontam entidades distintas de seu eu fracionado e sofrido. $\mathrm{O}$ fato de as personagens apresentadas em cena serem figuras solitárias poderia levar, nos dois espetáculos, a um relativo fechamento da atuação, como modo de marcar a segregação da figura retratada. Entretanto, as orientações artísticas nos dois casos não caminham na mesma direção.

Pedro Cardoso, após o agradecimento antecipado do início de seu espetáculo, afirma que sairá de cena por uns minutos para "vestir" a personagem e que voltará logo a seguir. Ao retornar ao palco, o ator, já no trabalho prometido de representação da personagem, sorri e dá pequenas gargalhadas em vários momentos, gargalhadas essas de teor ambíguo. São, ao mesmo tempo, da personagem e do ator e, além dessa ambivalência constitutiva, servem como estratégia teatral de condução do espectador para a descontração e o riso. Provocam e instauram a reação desejada: a gargalhada descontraída e amigável da audiência.

Prossegue, em grande parte, a relação de cumplicidade proposta a princípio. A segregação subjetiva e social do personagem não promove uma retração particularmente acentuada do ator na relação com o público. Retração essa que poderia ter um teor bastante inquie- tante, especialmente no caso de um comediante como Pedro Cardoso. Algo dessa retração é que me parece que se configura desde o início do espetáculo de Ana Kfouri. Em $O$ animal do tempo, o tipo de frontalidade trabalhada no espetáculo implica um tensionamento interno da atividade histriônica, assim como um estranhamento infinitamente mais marcado frente ao familiar e ao habitual do que aquilo que se vê em $O$ autofalante.

O próprio texto do dramaturgo francês Valère Novarina fornece inúmeros elementos de problematização da fala de tipo direto e frontal. Ao se deparar com os escritos das lápides tumulares, o falante em cena faz comentários como os que se seguem:

Este aqui diz: "tudo o que escreve o homem pelo homem é um falso, inclusive até essa inscrição". Mesma coisa seu vizinho que foi seu pai filho e vizinho. "Família Dumas". Olha, cão na minha cabeça: eis o túmulo da criança em frase curta: "Fugi da escola muito cedo. Agora recito todos os tempos aos meus ossos". "Aqui jaza, aqui jazerá e jazeria se estivesse ali, João das Pistas, ciclista profundo que deu uma guinada". "O mundo me oprimindo, eu deixo você agora só no presente nesse reduto de vingaria. Minha sombra aqui não dá mais medo nos carros". É o caído do Boulevard Blanqui (Novarina, 2007, p. 8).

Trata-se de um discurso monológico, internamente fraturado por vozes múltiplas e orientaçōes temporais diversas ("agora recito todos os tempos"). Essas fissuras internas, impedem que a fala se constitua como relato de situaçôes totalizáveis e internamente coerentes. Não há sujeito unificado e idêntico a si mesmo. No João que fala, há vários falantes autonomeados diferentemente pelo enunciador (João Sem-Nome, João Maquinal, João Segunda-Feira e Quarta-feira etc.). Também não se apresentam justificativas causais para a ruptura da unidade subjetiva, com base, por exemplo, em algum distúrbio psíquico do indivíduo, como é 
o caso da esquizofrenia da personagem de Pedro Cardoso. Em $O$ autofalante, a patologia explica e reduz a estranheza da personagem e das situações. Já em $O$ animal do tempo, é na linguagem mesma, até ao nível vocabular mais ínfimo, que se dá a interceptação do conhecido e do codificado por elementos alheios a cada unidade de sentido: "crianças brurras e drominadas, vocês dormirão quando deitados, entre o chuchu e vegetu no lugar do espírito" (Novarina, 2007, p. 11).

\section{II}

Além da marcada frontalidade da atuação, outra característica muito presente, em vários dos solos teatrais cariocas apresentados entre 2006 e 2007, é que o arcabouço ficcional de personagens e fábulas se atenua e ola artista se apresenta em nome próprio ante os espectadores. Dois exemplos dessa tendência são os espetáculos de Clarice Niskier ( $A$ alma imoral) e de Márcio Libar (O pregoeiro). Clarice chega ao palco, cruzando a platéia desde as últimas fileiras até atingir o espaço cênico. A atriz vem descalça, parece estar sem maquiagem e usa um vestido preto e longo. Vemos, depois, que o que parece um vestido é apenas um tecido envolvendo o corpo e permitindo, a partir de gestos simples e movimentos elegantes, o desnudamento da atriz em vários momentos. ${ }^{7}$

Ao subir ao palco, Clarice se dirige aos espectadores, desejando-lhes boa noite e explicando-lhes como surgiu a idéia do espetáculo teatral cuja apresentação se inicia. Menciona um programa de televisão ao qual tinha ido para dar uma entrevista, com o objetivo de divulgar outra peça em que estava atuando na ocasião.
Tratava-se de um programa de mesa redonda e, ao lado da atriz, havia um rabino (Nilton Bonder) que fora falar sobre seu último livro. O tema da religiosidade estava em foco no debate e a atriz, então, se disse judia, ligada aos preceitos religiosos judaicos, mas também simpatizante do budismo.

Clarice Niskier conta ainda aos espectadores que a produção do programa, enquanto este ainda estava no ar, recebeu um telefonema de uma espectadora de nome Léa, que se mostrava bastante irritada. A espectadora teria se apresentado como integrante da comunidade judaica e protestado veementemente contra a impostura que estaria contida na auto-apresentação de Clarice como judia e budista. Conforme relembra a atriz, Dona Léa (como passa a tratá-la a artista depois da menção inicial à telespectadora) afirmava que ou "bem se é judeu ou bem se é budista", mas que ser as duas coisas ao mesmo tempo é impossível.

A artista fala do fato ocorrido de modo leve e em tom de certa auto-ironia em relação à sua ambigüidade pessoal revelada na emissão televisiva, angariando, agora, os sorrisos amigáveis e cúmplices do espectador no teatro. Espectador esse com o qual ela estabelece, assim, uma relação que se quer direta e quase não mediada por qualquer estrutura ficcional (personagem, ação dramática etc.) ou aparato cênico (como cenários, diferentes figurinos e adereços). A apresentação marcadamente despojada e o fato de a artista falar em nome próprio são elementos que configuram uma imagem de verdade e sinceridade pessoal. Parcialmente esquecido de que está diante de um artefato ou constructo cênico, o espectador embala-se na discreta ternura e leveza da atriz, com quem estabelece uma relação fraterna de confiança e

7 O espetáculo de Clarice Niskier, concebido pela atriz, que contou com supervisão de Amir Hadad, estreou na sala Multi-uso do SESC Copacabana em 2006. O cenário é de Luis Martins; o figurino de Kika Lopes; a direção de movimento, de Márcia Feijó. Assisti o trabalho na temporada do Teatro Leblon, em julho de 2007. 
empatia. Não se trata de uma identificação ilusionística com algum personagem claramente ficcional, mas de uma identificação sentida como direta com a atriz.

O livro de Nilton Bonder claramente não constitui um texto dramático e nem se trata de uma obra propriamente literária, seja de caráter lírico ou ficcional, mas, sim, de um discurso teológico-filosófico. Ainda assim, a atriz decidiu encená-lo em decorrência, como nos explica, da orientação fortemente libertária da obra e do fato de ela falar de coisas que a própria atriz gostaria de ter dito à Dona Lea. Desse modo, o objetivo do trabalho é apresentado como o de manifestação pessoal da artista frente a temas variados (a ética, a alma, as relações humanas, etc.), conforme esses temas são tratados no livro de Bonder.

No espetáculo Não sou feliz, mas tenho marido, ${ }^{8}$ Zezé Polessa, como sua colega Clarice Niskier, chega ao palco, cruzando a sala desde o fundo da platéia. Mas, Polessa, ao contrário de Clarice, está caracterizada e não fala em seu próprio nome. A personagem que interpreta está em uma noite festiva e é mostrada dando uma entrevista, que antecede a sessão de autógrafos do lançamento de seu livro Não sou feliz, mas tenho marido. A atriz usa um vestido rosa e um pequeno paletó de algodão igualmente rosa, cor que é também a de seus sapatos, num estilo que o espectador não entende como sendo o da artista, mas o da jornalista que ela representa.?

A personagem retratada foi, a longo de muitos anos, uma mulher de classe média, uma dona de casa dedicada ao marido e aos filhos. Renunciara à sua atividade profissional durante a vigência de seu casamento pequeno-burguês, casamento esse que terminou em divórcio depois que o marido já maduro contraiu nova re- lação amorosa com uma jovem que tinha a idade de seus filhos já crescidos. Assim é que se criara a situação pessoal que teria permitido à personagem voltar à sua atividade profissional abortada na juventude. Ela passa a se responsabilizar, então, pela coluna feminina de um jornal diário de grande circulação. A atriz, ao cruzar a sala em direção ao palco, tem em mãos uma taça de vinho branco e ouve perguntas que soam nas caixas de som e que simulam questôes dirigidas a ela pela audiência da entrevista que a escritora estaria concedendo naquele momento.

Os aspectos constitutivos da personagem (seu comportamento pessoal, suas reações, seus afazeres cotidianos) e as situações de que ela fala (os momentos em que ela e o marido estiveram adoentados, o processo de construção da casa de praia etc.) configuram, no interior da narrativa, o contexto social de classe média ao qual a narradora pertence. Esse contexto de classe média se mantém depois que Viviana se torna a profissional independente, que lança agora seu livro. Muda o horizonte pessoal, mas não a inserção e a perspectiva de classe da jornalista, que, presumivelmente, tem um público constituído, em sua maioria, por leitoras que, provavelmente, pertencem ao mesmo estrato social e se identificam com a história de vida da autora, nela projetando sua própria trajetória de libertação do esquema doméstico ou seu desejo de vir a atingir essa libertação. Trata-se, muito possivelmente, no que tange à apreensão dos textos jornalísticos da autora, de um esquema simples de recepção baseado na identificação quase folhetinesca do público com o discurso da jornalista responsável pela coluna feminina do periódico em que escreve. A recepção dos espectadores de Zezé Polessa não e muito diferente. Baseia-se em uma identificação fácil e imediata,

8 Assisti ao espetáculo na temporada do Teatro Clara Nunes, Rio de Janeiro 2007.

9 A dramaturgia é baseada no livro autobiográfico homônimo ao espetáculo, escrito por Viviana Gómez Thorpe e adaptado por Zezé Polessa, Victor Garcia Peralta e Maria da Luz. A direção da peça é de Victor Garcia Peralta.Os figurinos foram criados por Alexandre Herchcovitch.. 
mesmo considerando a platéia masculina que também reconhece os elementos familiares dos episódios revividos em cena.

Enquanto o palco em que se apresenta Clarice Niskier está praticamente vazio (como o de Pedro Cardoso), tendo apenas uma cadeira para uso da atriz, vemos, no espetáculo de Zezé Polessa uma construção cênica constituída por grandes pilhas de livros. ${ }^{10}$ São grandes volumes distribuídos pelo palco e construídos de modo sintético como elementos estruturais que se repetem com variações de altura e de formato. Esses blocos ou volumes fazem menção, de modo puramente alusivo, a uma espécie de estoque da obra publicada. Obra aquela que é agora lançada e autografada em evento público. A atriz se move entre os blocos, de um metro e meio a dois metros e meio aproximadamente, mas ela utiliza também as superfícies superiores dos blocos.

Não há mimese cenográfica realista dos espaços domésticos rememorados e nem de uma livraria ou salão em que possa estar se dando a entrevista da autora e a noite de autógrafos de seu livro. Ao nível icônico efetivo, o que se configura, de modo minimalista, e não de forma naturalista minuciosa, é o estoque de livros, uma espécie, portanto, de local de armazenamento. É de um armazém de exemplares da obra, de páginas do livro, de memórias do passado, de respostas à entrevista que se trata na peça de Zezé Polessa.

Antes de o espetáculo ter início, o espectador vê, em uma grande tela de projeção ao fundo do palco, imagens de livros abertos ou sendo folheados. $\mathrm{O}$ vídeo não mostra ninguém em atividade de leitura. Mas imagens de livros cujas folhas vão passando, vão sendo viradas pouco a pouco, como se impulsionadas por leve brisa ou por outro fator invisível. ${ }^{11}$ É, de certo modo, esse fator não visível, não espacializável iconicamente, que a peça quer abordar. É a passagem do tempo que a imagem tenta apreender. É do tempo, da vida passada de uma personagem e de um livro que procura capturar esse tempo que se fala. É a partir desse livro que se constitui o passado da personagem Viviana, que é autora da obra autobiográfica homônima ao espetáculo, no qual se teatralizam os conteúdos relatados pela jornalista Viviana Gómez Thorpe.

Aos espectadores a quem Zezé Polessa se dirige é atribuído o papel ficcional de membros da audiência daquela espécie de entrevista coletiva que é dada pela escritora. Desse modo, Zezé Polessa e os demais criadores de seu espetáculo constroem uma estrutura ficcional organizada teatralmente em pelo menos dois níveis narrativos. Um desses níveis é aquele em que Viviana é entrevistada ao vivo na noite de lançamento de seu livro. O outro é o plano em que a vemos revivendo as situações de seu passado familiar ante os entrevistadores do presente.

É no interior desse arcabouço dramatúrgico e narrativo razoavelmente cerrado, que se expõe Zezé Polessa. Possivelmente a atriz tenha tido, ao contrário de Niskier, a necessidade de ostentar a mediação cênica para marcar precisamente uma distância pessoal frente à autora do livro dramatizado. É como se, no caso de Zezé Polessa, houvesse a necessidade de explicitar que há dois discursos femininos distintos entre si, o da autora e o da atriz. Desse modo, sob a afetação de Viviana, circula um segundo discurso igualmente feminino e feminista, porém, mais indireto, mais reservado e menos acessível. Discurso esse possivelmente menos suscetível de ser esvaziado por processos de banalização próprios das mídias hegemônicas.

10 A cenografia e Direção de Arte de Não sou feliz, mas tenho marido é de Gringo Cárdia, enquanto Maneco Quinderé assina a iluminação.

11 Os vídeos foram criados por Wallace Cardia e Rico Vilarouca, com coordenação de Gringa Cardia e da Mesosfera Produções, conforme informação constante do programa da peça. 
A intérprete contorna o campo das dicotomias simplistas, optando por uma solidariedade ambivalente com a personagem representada, dentro da relativa distância que toma por meio da atuação levemente desnaturalizada e teatralizada, com traços caricaturais discretos usados na composição da personagem. A atriz não poderia lançar mão da ficção de uma ausência completa de entrecho e de fábula, ficção constituída pelo mito de uma comunicação totalmente direta e completamente não mediada com o público. Ficção do não teatro e da não ficcionalização, a que a construção da sinceridade precisou recorrer no espetáculo de Clarice Niskier.

Mas, vejamos o que se dá com outro espetáculo solo: $O$ pregoeiro, de Márcio Libar. $\mathrm{O}$ ator, depois de recepcionar e saudar os espectadores, enuncia as seguintes palavras:

Quem aqui já viu o meu show? Pra quem já viu, eu queria avisar que é aquilo mesmo. Pra quem não viu, fica tranqüilo que não é show de Reggae não. Eu preciso de uma hora da atenção de vocês, só uma hora. Pra contar pra vocês qual é o sentido da arte de ser palhaço. Pra isso, eu vou começar apresentando... A mim mesmo. ${ }^{12}$

Márcio, em sua fala de abertura do espetáculo, já se posiciona em diversos aspectos.
Classifica sua performance cênica como um "show" individual. Por meio dessa designação do trabalho, aproxima-se duplamente do universo $p o p$ da música de consumo e do universo das exibições individuais de artistas de rua mais ou menos anônimos. O termo "show" pode ser usado pelo artista popular das ruas, com alguma pompa, como uma tentativa ingênua de auto-inserção no campo das atividades artísticas da esfera legitimada pelo consumo em larga escala. Trata-se, nesse caso, de um gesto mimético do oprimido em relação ao campo hegemônico. Mas o recurso ao termo "show" pode também ser usado como modo burlesco de parodiar a cultura de massa, como ironia e declaração de independência.

A singeleza da palavra "show" na fala inicial de Márcio Libar é apenas aparente. Ela afasta qualquer idéia de neutralidade. Contém, ao contrário, a escolha clara de certas perspectivas artísticas em detrimento de outras. Politiza o discurso, por meio do destaque a um termo, que poderia indicializar um campo de experiências percebido como pouco politizado, de cunho estritamente espetacular. ${ }^{13} \mathrm{O}$ que se afirma com a atitude nada ingênua de Libar é a idéia de que o homem comum, o consumidor alienado - e oprimido em meio aos shows e simulacros que lhe são impostos pela sociedade de controle contemporânea ${ }^{14}$ - encontra seus meios de resistência, suas táticas astuciosas, que os intelec-

12 O programa da peça se refere ao espetáculo como "uma criação coletiva de Márcio Libar" e acrescenta a essa indicação que "isto envolve: roteiro, direção, trilha sonora, figurino, cenário, seleção de elenco, dramaturgia e uścaraio". As citações do texto de Libar feitas neste ensaio tiveram como fonte a transcrição realizada por Eduardo Katz e o vídeo da peça. Agradeço a Marcio Libar e a Eduardo Katz pelo acesso ao texto e o vídeo. Assisti o espetáculo na Casa da Gávea, Rio de Janeiro, em julho de 2007.

13 Na teorização de Guy Debord sobre a noção de espetáculo, esse termo se refere a um conjunto de meios de dominação e controle das populações (Debord, 1997). A reflexão de Jean Baudrillard sobre o simulacro pode também se associar à idéia de espetáculo para a reflexão sobre os mecanismos de poder e nas sociedades contemporânea (Baudrillard, 1991).

14 A noção de sociedades de controle, ligadas ao poder capitalista na era digital e do marketing, é trabalhada por Deleuze (1992, p. 219-26) como desdobramento da conceituação foucaultiana de sociedades disciplinares, nas quais o poder produziu, conforme o autor, corpos dóceis e úteis por meio das várias formas de confinamento, verificáveis do final do século XVIII à primeira metade do XX (Foucault, 2005). 
tuais que abraçam estratégias e perspectivas revolucionárias tradicionais, nem sempre chegam a conceber como possíveis. ${ }^{15}$

No início de seu espetáculo $O$ pregoeiro, ao utilizar a palavra "show" e não "peça" ou "drama”, Márcio Libar indica, de cara, dentre outros aspectos, que ele pretende fazer uma performance na qual se coloca em nome próprio. Libar dispensa a estrutura da fábula e do personagem como meio para manifestar suas visões de mundo. Dispensa esse tipo particular de constructo representacional, como instrumento para tomar posições individuais e para agenciar modos alternativos de subjetivação e identificação coletiva. Não é sob o esquema mais ou menos erudito e canônico do teatro dramático, da máscara de um personagem ficcional mostrado no interior de um microcosmo fabular mais ou menos fechado (dramático) ou aberto (épico), que se manifestará o artista.

Mas a dispensa de estruturas eruditas e canônicas não implica, no espetáculo de Libar, nem a adesão a qualquer anti-intelectualismo acrítico, nem a afirmação de qualquer verdade substancial supostamente contida nas relações inter-pessoais que se presumam diretas e não mediadas. Não se verifica tampouco o retorno à mesma noção de povo como ela se tornou significativa para a produção cultural no Brasil nos anos 1960. Momento no qual, por meio da idéia de povo, privilegiavam-se, como objeto da representação artística, os setores oprimidos das populações, ainda que se dirimissem, no mesmo movimento, as diferenças de tipos de opressão (decorrentes de questôes raciais, de sexo, de orientação sexual, de região em que se habita e de outras circunstâncias). Diferenças de tipos de opressão essas que poderiam, caso fossem enfocadas, evidenciar modos particulares de dominação e controle além da opressão tradicionalmente priorizada pela perspectiva marxista, que é a opressão de classe. ${ }^{16}$

É complexo e rico de tensões internas o modo como Márcio Libar fala em nome próprio sem constituir nenhuma figura de sujeito forte e fixa (sem a configuração de verdades substanciais). A identidade se define de modo operativo, algo a que se chega e que "funciona". É (ainda que não apenas) constructo superficial de linguagem ao nível vocabular e no plano dos meros significantes.

Meu nome é Márcio Libar, eu sou artista popular e como arte do palhaço, é arte da verdade, eu vou começar com a verdade sobre o meu nome. Meu nome verdadeiro não é Márcio Libar. Ficaram chocados, né? Meu nome verdadeiro é Márcio Lima Barbosa. Lima por parte de mãe, e Barbosa por causa do amigo do meu pai. É bom dar essa idéia, porque pobre quando quer ficar famoso, já pensa logo no sobrenome. Não tem nome

15 Michel de Certeau, diferencia a noção de estratégias (totalizáveis, "gerencializáveis" pelo poder) e de táticas (dispersas, circunstanciais, astuciosas e não suscetíveis de totalizações e submissão a estatísticas para uso institucional). $\mathrm{O}$ autor, faz menção, assim, aos modos de aproveitamento diferenciado e aos usos inauditos, que o consumidor, supostamente alienado, faz dos produtos e discursos que lhe são impostos, escapando parcialmente ao controle exercido pelas instituições de poder e pela ordem capitalista (Certeau, 1994). Ao me referir às perspectivas revolucionárias tradicionais, penso, por exemplo, no modo como Fredric Jameson faz restriçōes a certos discursos, como o da diferença, e a certas práticas políticas, como a dos grupos ou das chamadas minorias, em prol de conceitos priorizados pelo autor, como o de totalidade, para análise social, e o da luta de classes, na ação coletiva (Jameson, 1996, p. 321-56).

16 Dentre tantos autores que se debruçaram sobre a relação entre arte e política no Brasil nos anos 1960 e seguintes, poderia me referir aqui a trabalhos já antigos e bastante conhecidos de Heloisa Buarque de Holanda (Hollanda, 2004) e Renato Ortiz (Ortiz, 1994). 
bom, então se pergunta: Qual vai ser meu nome, qual vai ser meu nome? Resolvi pegar metade do nome da mãe, metade da outra banda da família. Deu essa coisa mais ou menos meio árabe, Libar, que funciona. E qual não foi a minha surpresa, quando eu vi que o meu nome era verbete de dicionário.

Mas a identidade que o "nome próprio" contém é também, no espetáculo de Márcio Libar, uma história de relações pessoais e deslocamentos vividos. $\mathrm{O}$ ator menciona suas viagens, pessoas encontradas, episódios esparsos flagrados em lugares e cidades distintas etc. A subjetividade é produto móvel desse trânsito ou de inserçôes circunstanciais em determinados contextos histórico-sociais. A identidade móvel e contingente inclui ainda a noção de fracasso.

O circo é um espetáculo que desafia a lei da gravidade. No circo, as pessoas voam. No cir$\mathrm{co}$, as pessoas se equilibram por um fio (...). Mas o palhaço é aquele que cai. O palhaço é aquele que erra. O palhaço é aquele que perde.

O artista enumera os esforços, que ao longo do tempo empreendera, e as habilidades que tentou desenvolver (tocar pandeiro, fazer acrobacias etc.), visando a obter a simpatia e a adesão do público. Em meio à enumeração dos esforços empreendidos para conquistar o amor de espectadores, ele mostra o ridículo e o fracasso de cada uma dessas tentativas erráticas de ser aceito, de ser querido, poderíamos dizer, também, de ser legitimado, de ter direito à fala. O ridículo no caso é não ter percebido logo que a legitimação depende de um aparato que não é neutro, mas parcial, comprometido sempre com certas posições de poder e de classe. Essa idéia não é tematizada de modo direto ao nível verbal. Ela é apreendida do comportamento atual do artista e de sua ironia constante, que expressam o contrário de qualquer subserviência a critérios e valores canônicos de julgamento do trabalho artístico.
Em meio à sua narrativa cômica e autoirônica de como se tornou artista, Libar alude à sua origem social e mostra fotos de familiares queridos (seus pais, sua avó, sua filha). Há também a fotografia do palhaço Benjamin, ao qual o ator se refere como primeiro palhaço negro do Brasil, em cuja família artística, por assim dizer, Libar opera uma espécie de auto-inserção. $\mathrm{O}$ tom não é nem de longe melodramático ou nostálgico. Trata-se antes de um agenciamento político preciso, da assunção de uma perspectiva histórica específica, de um modo de subjetivação coletivo do qual como sujeito delibera participar. Libar faz ainda menção a artistas aos quais tem como referências importantes (o diretor teatral Amir Haddad; seu mestre de palhaçaria, Nani Colombaioni). Em meio a tudo isso é que o nome próprio e a identidade individual aparecem como construção e contingência, como interação e como produto da dinâmica histório-social, da qual o performer se mostra amplamente consciente e na qual se move sem ingenuidade.

Libar afirma, ao início de seu espetáculo, que os espectadores não precisam se preocupar, pois não se trata de um show de reggae. Isso é uma brincadeira com o fato de o ator ser um homem negro, apresentando comportamentos e trejeitos identificados como assumidamente urbanos e mesmo cariocas, e de usar cabelos rastafari longos. Não será mesmo um show de música reggae o que se fará. Mas não deixa de ser um show de reggae, se entendemos esse qualificativo não apenas como gênero musical, mas como atitude subjetiva e política referida a uma manifestação cultural específica, latinoamericana, cujos traços de identidade se definem como negros, urbanos e cosmopolitas. Traços esses que se distinguem das identificaçóes folcloristas ou tradicionalistas da cultura afro-descendente na América Latina. Então, o espetáculo solo de Libar não é, de fato, e não deixa de ser, de algum modo, um show de reggae. Não é à toa, que em certo momento de sua performance, Libar faz o seguinte comentário carregado de ironia e de auto-ironia: 
[...] um negócio que me deixa bolado, é ser chamado de Bob Marley. É impressionante. Só andar na rua e neguinho começa. "Qualé Bob", "e aí Bob", do outro lado da calçada, "fala Bob". Abre a janela do ônibus e fala: "Qualé Bob Marli", e neguihno fala "Bob Marliii!!!” Outro dia eu tava no Camelódromo da Uruguaina, um cara chegou e disse: "Aí neguinho, tu trabalha com essas porra de Bob Marley?” Fiquei olhando pro cara, sem saber o que dizer. E ele: "Tu trabalha com essas porra de Bob Marley ou não trabalha, maluco?" "Tu quer saber o quê cara, se eu estampo camisa, se eu vendo bagulho, se eu toco reggae, o quê que tu quer saber?” Ele: "ãh, âh, tu trabalha com essas porra de Bob Marley e não quer me falar". Os caras acham que Bob Marley é emprego, que Bob Marley é ONG?

O espetáculo $O$ pregoeiro é dividido em duas partes. Na primeira, Márcio Libar se apresenta e fala de sua trajetória, de sua aproximação do circo e, em especial da arte do palhaço que ele diz que enfocará em sua peça. $\mathrm{Na}$ segunda parte do trabalho, vemos o Cuti-cuti, uma figura clássica de palhaço com seu nariz vermelho e sua cartola. É um momento de características líricas em que se alude à fragilidade, ao equívoco, ao gesto fracassado, objeto de riso, mas também de empatia, pelo que tem de infantil e simplório. É intensa a pletora verbal do ator na primeira parte, enquanto, na segunda, quase não há palavras e as poucas pronunciadas são meramente balbuciadas, aspecto que ajuda na concretização de uma imagem de fragilidade da figura que vemos em cena. Há um efeito de encantamento provocado sobre a platéia. $\mathrm{O}$ espectador se deixa embalar pela doçura de Cuti-cuti e comove-se com a ingenuidade do palhaço, com seus múltiplos erros e com sua inocência pueril. Nessa parte, apresenta-se uma estrutura ficcional um pouco mais definida do que a da primeira metade do espetáculo, uma vez que vemos o Cuti-cuti no interior de certas situações cômicas. Porém, mais do que como propriamente ficcional, essa estrutura se configura antes como lírica. É que não chega a se desenrolar uma ação ou argumento, mas gestos mais ou menos isolados e repetidos, sem se distribuírem em um desdobramento sintagmático linear. De fato, o elemento de ficção destacado não é o andamento de uma fábula ou de uma ação dramática no tempo. Há apenas um arcabouço de personagem: marcado pela incompletude, pela minoridade e solidão. Repete-se uma ação associada a módulos semelhantes de significação nos vários momentos (insucesso nos gestos e movimentos, comportamento equivocado e infantil, sensação de que os objetos conjuram contra o sujeito em sua tentativa fracassada de manipulá-los etc.).

A relação entre depoimento (que se evidencia mais na primeira parte de $O$ pregoeiro) e ficção (que se constitui, especialmente na segunda parte do trabalho, como esboço lírico de quadros sintéticos do palhaço Cuti-cuti) é mais corrosiva no caso de Libar do que no trabalho de Polessa. A interferência recíproca de elementos pertinentes a gêneros distintos entre si (depoimento pessoal e estrutura lírica dos esquetes clownescos) serve, no caso de Libar, a uma desestabilização de qualquer imagem segura e inteiriça de sujeito disponibilizada ao reconhecimento ao receptor. A identificação do público com a figura humana que está em cena, em cada uma das duas partes do espetáculo, implica a aceitação de elementos de fragilidade e de incompletude como constitutivos da auto-imagem do receptor. Esse efeito é próprio do modo como o ator se utiliza dos jogos do palhaço, tanto no trecho em que se apresenta como Márcio Libar, quanto na segunda parte, em que vemos o Cuti-cuti.

\section{III}

Gostaria de mencionar ainda alguns espetáculos não referidos até aqui. Pretendo chamar a atenção, mais do que o fiz até agora, para o tema das concepçóes de teatralidade e do trabalho de 
ator, no interior do jogo que estou tentando tecer com os aspectos que tiveram mais destaque até aqui: a frontalidade da atuação e o caráter mais ou menos ficcional e dramático ou de depoimento auto-referente do discurso encenado. O objetivo continua sendo o de discernir as políticas e os modos de subjetivação agenciados na e pela cena teatral, por meio da abordagem desses espetáculos solos tão numerosos no circuito carioca recente.

$\mathrm{O}$ ator Edwin Luisi, em Eu sou minha própria mulher, ${ }^{17}$ representa uma série de personagens no interior de um monólogo dramático, no qual se apresenta a história verídica de Charlotte Von Mahlsdorf, pseudônimo feminino do alemão Lothar Berfeld, homem que se traveste de mulher desde a adolescência e que vive em Berlim tanto sob o governo nazista, quanto, posteriormente, sob o domínio comunista. A peça é produto de técnica dramatúrgica apurada, por meio da qual o autor organiza obra de ficção teatral, selecionando momentos fortes da trajetória de vida da personagem Charlotte (a cena em que sua tia lésbica a flagra experimentando roupas femininas ainda quando adolescente, o enfrentamento com seu pai e o assassinato deste último, os encontros com o amigo que será preso e morto pelo governo autoritário, etc.), dispostos em episódios concentrados e sintéticos. O pano de fundo histórico é configurado para dar mais relevo à individualidade particular e desviante de Charlotte, que é mostrada exclusivamente dentro das situaçôes dramatizadas com técnicas, evidentemente, modernas, correspondentes a uma concepção épico-narrativa do texto teatral e não a uma visão ortodoxa da obra dramática. Vemos, no monólogo representado por Luisi, uma galeria de numerosos personagens com os quais se defronta a figura destacada pelo dramaturgo, a de Charlotte.

$\mathrm{O}$ ator é levado a acompanhar o escritor no exercício de virtuosismo técnico. Como não há praticamente qualquer variação de adereços, figurinos e elementos materiais de caracterização das personagens, ${ }^{18} \mathrm{o}$ intérprete deve recorrer a pequenas variações vocais e de composição dos gestos e das atitudes. A sinceridade ou verdade aqui é de tipo muito distinto daquela que leva Clarice Niskier a entrar descalça pela platéia e a mostrar-se literalmente nua, enquanto fala diretamente aos espectadores ao longo do espetáculo. Ao contrário do que se constitui na peça de Niskier, a força do intérprete de Charlotte só se dá sob o seu desaparecimento em prol da personagem, com a qual se veste o ator e a qual ele destaca, em meio ao leque de outras figuras, que também representa ao longo da peça. A verdade está ligada à singularidade da personagem e de sua concretização cênica pelo ator, ou seja, aos conteúdos narrativos e às situaçôes representadas, das quais decorrem possíveis percepções mais amplas sobre a vida em sociedade e sobre a subjetividade humana.

No palco de Edwin Luisi, vemos duas escrivaninhas nas partes laterais da cena. Elas estão à esquerda e à direita de um suporte, sob a forma de uma colunata clássica, em que repousa um grande gramofone dourado. A atmosfera é de austeridade, decorrente dos objetos de antiquário do século XIX colecionados por Charlotte e dispostos na cena. ${ }^{19}$ Há poucos

17 Premiada peça de autoria do dramaturgo Dough Wright apresentada no circuito off-Broadway, em Nova York, durante o ano de 2003 e, depois, exibida com sucesso, na Broadway, em 2004 e 2005, apresentada no Rio de Janeiro, no Teatro Leblon (Sala "Tônia Carreiro") em 2007, sob a direção de Herson Capri e Susana Garcia.

18 O cenário e o figurino de Eu sou minha própria mulher foram criados por Marcelo Marques.

19 Além da cenografia, a iluminação assinada por Paulo César Medeiros colabora também com a criação do tom de severidade que caracteriza o espetáculo. 
elementos cenográficos, mas não se trata da ostentação do palco vazio, da radical recusa à figuração icônica, que é o que testemunhamos no espetáculo de Clarice Niskier, que só conta com uma única cadeira, simples e despojada, colocada sobre o palco e voltada para os espectadores. O contexto da vida doméstica de Charlotte é cuidadosamente constituído, ainda que por meio de elementos sintéticos e indiciais e não com o recurso de uma composição minuciosa e totalizadora. A totalidade do ambiente é apontada de modo mentonímico por meio dos poucos elementos efetivamente disponibilizados ao olhar do espectador.

A elegância do travesti e da imagem aristocrática e séria que ele compóe para si, afastando qualquer atitude supostamente vulgar ou mesmo jocosa, acaba por contaminar de força aurática $^{20}$ o espetáculo de Luisi. Explico-me: não há qualquer quebra com uma atmosfera elevada e nem com a organicidade históricoficcional das situações retratadas. Nenhum paralelismo com outras situações e vivências de travesti é traçado, nenhum elemento díspar rompendo a coerência interna das circunstâncias em cada episódio teatralizado, nenhum espaço para uma fala-travesti de agora, uma falagay atual ou uma manifestação qualquer do ator em nome próprio hoje, nenhuma ingerência de um presente invasivo ou incontido perturbando a delimitação narrativa e temporal das situaçôes representadas. Vemos, assim, uma composição dramatúrgica razoavelmente fechada (apesar de não se tratar de um drama ortodoxo) e assisti- mos a um ator dramático no domínio extremo de técnicas consagradas da representação de personagens, com justificativa interior estribada rigorosamente nas circunstâncias retratadas.

Há também no espetáculo uma concepção bem determinada do belo (como composição internamente harmônica, que pressupõe, em seu delineamento, uma separação da vida prática e de seus interesses imediatos), uma concepção moderna de dramaturgia (épica e construída, no caso, sob a perspectiva de um narrador que é também personagem, isto é, o próprio autor que figura em cena) e uma visão específica da arte, da teatralidade e do trabalho do ator. Essa visão é que me parece limitar, na dramaturgia e na encenação, a força política que os temas do falso e do travestimento, bem como da subjetividade como livre produção poderiam ter em um espetáculo que tematiza a vida de um travesti. ${ }^{21}$

No espetáculo Minha mãe é uma peça do jovem ator Paulo Gustavo, ${ }^{22}$ o travestimento dá margem a projeto oposto ao de Luisi, no sentido da exclusão de qualquer traço de auratização da atividade artística e da representação teatral. Paulo Gustavo interpreta uma mulher de classe média, divorciada, mãe de um casal de filhos que entra na idade adulta. O rapaz é gay e a moça se interessa por teatro. Esses pendores dos filhos se juntam a outros fatores de inquietação da mãe. Paulo Gustavo usa vestido florido, tem bobs no cabelo, fala o tempo todo no espetáculo. Dirige-se aos filhos (ao telefone quando estão fora de casa, gritando-lhes desde a sala em direção ao quarto, do beiral da janela quando

20 Utilizo o adjetivo aurático, lembrando de Walter Benjamin, que teorizou sobre a noção de aura de modos diferentes em textos distintos. Penso aqui especialmente na abordagem contida no ensaio sobre a reprodutibilidade técnica da arte (Benjamin, 1987, p. 165-96) e leio a idéia de aura em conjugação com a promoção de atitudes de reverência, de caráter teológico e aristocrático, frente à criação artística.

21 Quando me refiro ao falso, penso nas potências do falso, como teorizadas por Gilles Deleuze para se referir a certos modos de composição da narrativa e da imagem cinematográfica, modos esses que não levam a uma sensação de estabilidade, de totalidade e de fixidez do real, nem tampouco à distinção clara entre dimensões como vigília e sonho, realidade e imaginário (Deleuze, 2005, p. 155-67).

22 O espetáculo, dirigido por João Fonseca, tem texto de autoria do próprio ator e estreou em 2007 no Cândido Mendes, Rio de Janeiro. Assisti ao espetáculo no Teatro dos Quatro. 
eles saem ou chegam no edifício, etc.). Conversa com vizinhas pelas janelas e com outros interlocutores que não vemos nunca, a não ser em nossa imaginação, estimulada pelas ações e reações da personagem de Paulo Gustavo, personagem que, quase todo o tempo, é flagrada na sala de estar do seu apartamento em meio às suas atividades domésticas cotidianas.

Há, evidentemente, traços de caricatura na composição da personagem (de seus trejeitos, de seus tiques nervosos, de sua voz esganiçada), mas não se trata de um humor depreciativo da mulher representada. Ao contrário, é com empatia que o ator-dramaturgo constrói a imagem da mãe meio neurótica e da dona de casa obsessiva, aprisionada na repetição de gestos dos quais não consegue se libertar, como não pode enxergar também que seus filhos já cresceram e já não precisam tanto dela. Desde a primeira aparição de Paulo Gustavo, vemos nele a personagem interpretada pelo ator. Não há prólogo em nome próprio, como no caso de Pedro Cardoso em $O$ autofalante, nem discurso assumido como do próprio performer e dirigido diretamente à platéia como nos casos diferenciados dos trabalhos de Clarice Niskier e de Márcio Libar.

No palco de Minha mãe é uma peça estão dispostos um sofá e uma mesa de centro. Ao fundo, há uma janela. Os elementos cenográficos são poucos e razoavelmente econômicos, mas suficientes para concretizar cenicamente o espaço da ação representada. Quanto às opções cenográficas, a encenação se diferencia do espaço cênico minimalista e não figurativo da peça de Zezé Polessa e se aproxima, de certo modo, da iconização mimética e anedótica (ainda que metonímica e não totalizadora) do palco de Edwin Luisi. O espaço cênico não se reduz, no espetáculo de Paulo Gustavo, a uma pura área de atuação, como ocorre no trabalho de Pedro Cardoso. Em $O$ autofalante, a personagem internamente dividida em seu eu fracionado é mostrada em lugares variados: na rua, dentro de um ônibus, em sua casa etc. Mas a concretização imaginária desses lugares na recepção se dá por meio dos puros recursos atorais e dos dados nar- rativos distribuídos no texto escrito e falado por Cardoso. Ou seja, dispensa-se rigorosa e completamente qualquer elemento cenográfico, seja ele de caráter icônico-figurativo ou de estrutura funcional, abstrata e sintética.

Mas, se em Minha mãe é uma peça não vemos o palco radicalmente vazio, o espaço representado é auto-reflexivamente desmontado. É reduzido, afinal, também ele, a puro espaço da representação, como a cena de $O$ autofalante, ainda que por outros procedimentos que não o da exclusão literal de elementos cenográficos. O microcosmo fabular representado na peça de Gustavo perde parcialmente a importância frente à intensidade do jogo do ator com o espectador.

Essa desconstrução relativa da importância do espaço fabular em prol do puro jogo performático é um traço da estrutura geral do espetáculo, mas se tematiza auto-reflexivamente em um momento particular da peça. Trata-se da cena em que a personagem vai ao teatro no qual se dará um teste para atores. Nesse momento, o objetivo da mãe representada por Paulo Gustavo é evitar, junto aos produtores da peça para a qual se escolhe elenco, que sua jovem filha seja escolhida para compor a equipe do trabalho teatral, equipe que se integralizará com os resultados do teste que ocorrerá no dia seguinte e para o qual a filha já fizera sua inscrição.

Nessa cena, de alta fatura cômica, o intérprete se dirige abertamente aos espectadores (aos quais é atribuído, assim, o papel ficcional de técnicos e artistas que trabalham no teatro). $\mathrm{O}$ ator rompe, de forma intensamente burlesca, a quarta parede. A personagem totalmente estranha ao metier teatral, carregada de preconceitos e ignorante do universo em que se dá tal metier, interrompe o ensaio de uma peça, em busca de falar ao diretor do espetáculo que se realizará naquele teatro. A mãe pretende convencer o diretor de que sua filha não deve ser a escolhida para o elenco ainda incompleto.

$\mathrm{Na}$ cena da mãe aflita quanto ao futuro de sua filha e carregada de preconceitos contra o mundo do teatro, a ruptura operada no espa- 
ço do enunciado ficcional (por conta de uma certa autonomização conquistada pelo jogo de cena) ilustra que o procedimento representacional de Paulo Gustavo é totalmente diferente daquele de Edwin Luisi e se aproxima, em vários aspectos, dos tipos de atuação de Clarice Niskier, de Márcio Libar e de Pedro Cardoso. Há também algo que se fala em nome próprio na peça de Gustavo. O jogo do falso e do travestimento funciona como um modo de desconstrução das identidades fixas. É difícil não ver no trabalho de Paulo Gustavo certa dimensão citacional das performances de drag quens e transformistas do mundo gay. Não se trata exatamente da mesma coisa feita pelas drag queens, mas a atuação de Gustavo se conecta de modo paródico - dentre outros campos histriônicos, aos quais se associa, a exemplo da comédia popular televisiva - com os shows de certos transformistas que apelam para o exagero e o burlesco em suas auto-performances do feminino, ao invés de desenharem gestos miméticos da suposta mulher real.

\section{IV}

Mas passemos a outro espetáculo: Homem bom$b a$, de João Carlos Artigos, na tentativa de dar conta das políticas agenciadas como produção de sentido por solos cariocas recentes. O trabalho de Artigos tem uma estrutura ambivalente de ficção e de memórias autobiográficas, havendo no texto também uma série de comentários mais gerais sobre as relaçôes de dominação entre os seres humanos, sobre valores éticos e so- bre a arte do palhaço. ${ }^{23}$ Esses comentários são distribuídos ao longo do espetáculo e decorrem da situação representada (uma animação de festa de um menino rico feita pelo artista). No início do trabalho, vemos um vídeo, no qual uma mulher que parece ser alguém de classe média alta ou da burguesia fala ao telefone com o Palhaço Seu Flor, encomendando-lhe um serviço de animação para a festa de aniversário de seu filho Pedro. ${ }^{24}$ Ainda no vídeo, o espectador acompanha o palhaço Seu Flor, carregando sua bagagem cênica (composta de malas de tamanhos variados e decoradas com decalques coloridos) e chegando ao edifício em que ocorrerá a festa do menino Pedro.

O espetáculo encena a comemoração, que, além do aniversariante, tem a presença de apenas mais três amiguinhos (dois meninos e uma menina) e é guarnecida com "uma mesa de comidas e refrigerantes" que, segundo o comentário do Seu Flor para a platéia ante a qual rememora o evento, "dava para alimentar várias crianças de rua" durante longo tempo. Logo de cara, o aniversariante diz que não gosta de palhaços, mas ainda assim, o seu Flor tentará com vários números atrair a atenção e a simpatia de Pedro e seus colegas (as quatro crianças sendo representadas por bonecos estáticos dispostos ao fundo do espaço cênico). Há o número de Iorick (um pequeno cachorro de pelúcia), que dará saltos mortais e acabará carbonizado pelas chamas do aro que o cão cruza em seu salto; o quadro de Igor, o exterminador de palhaços; a cena do Homem-suco etc. Todas as tentativas de agradar que são empreendidas pelo artista são sistematicamente desdenhadas e rejeitadas por

23 O espetáculo solo de João Atigos, tem dramaturgia e concepção assinada em parceria pelo ator e por Leo Bassi. O programa indica o nome de Sidney Cruz como ensaiador, além de apresentar leo Bassi como responsável pela direção geral. O espetáculo começou a ser exibido em 2006 (Rio de Janeiro: Espaço Cultural Sérgio Porto). Assisti o trabalho duas vezes, em 2007, no espaço do Teatro de Anônimo, grupo a que pertence João Artigos, e que é sediado na Fundição Progresso, na Lapa (Rio de Janeiro). Agradeço ao ator a disponibilização do vídeo do espetáculo.

24 O programa da peça indica a direção de arte do vídeo como sendo de Asduas e a produção do vídeo da empresa Filmes do Serro. 
Pedro, que diz, dentre outras coisas, que viu palhaço de verdade no Cirque du Soleil em viagem feita com os pais a Miami, que Seu Flor é um vagabundo e um morto de fome, pois se fosse um artista de verdade estaria na televisão ou no próprio Cirque du Soleil.

Os procedimentos circenses usados pelo palhaço seu Flor incluem um leque variado de atraçôes: atos de malabarismo (praticados com frutas), de equilibrismo (usando uma das malas da bagagem do palhaço, mala que ele equilibra pelo vértice em sua testa), de fantasia (como o número em que a mala vira um palquinho no qual é animado um pequeno corpo de boneco antropomórfico - o personagem Igor, o exterminador de Palhaços -, cujo rosto e cujas mãos são os do próprio ator animador). Os espectadores - que assistem ao ator João Artigos, que rememora a festa do menino Pedro animada pelo artista - também presenciam essas habilidades circenses. Elas são expostas agora como instrumentos pueris da atividade do artista. A gratuidade dos recursos de que lança mão o Palhaço Seu Flor/João Artigos se mostra ao mesmo tempo em que se evidencia que o único jogo teatral que interessaria ao menino Pedro - em sua auto-imagem de sujeito pertencente à classe dominante - seria aquele pelo qual se confirmasse a sua posição social.

Há um conflito entre duas posições de sujeito. Em um dos lados do confronto, está o personagem Seu Flor (João Artigos), identificado com o campo social periférico (o ator se diz proveniente da periferia do Rio de Janeiro e se identifica com o palhaço Benjamin de Oliveira, que é apresentado como um ex-escravo que se tornou o primeiro palhaço negro do Brasil, na fase inicial da vida republicana no país). Do outro lado, encontra-se o menino Pedro como representante das classes hegemônicas e das forças centrais. A peça não mostra situações em que se defrontem de modo direto e literal patrōes e empregados, em um ambiente cotidiano de trabalho ou em um confronto sindicalista. Não se ilustram pedagogicamente, como se fazia em certa arte política do início dos anos 60 no Brasil, os procedimentos que supostamente o oprimido deveria adotar rumo à sua organização coletiva e em prol de sua libertação relativamente aos elos de opressão social. O que se produz no espetáculo é a recusa de se fazer qualquer representação do mundo contemporâneo como um universo harmônico e pacificado, de se fornecer uma imagem de feliz reunião dos diferentes que a idéia de circo e a exibição mais ou menos lírica de um palhaço inocente para espectadores irmanados num mesmo sentimento de empatia poderia sugerir.

A condição periférica do Palhaço Seu Flor não diz respeito apenas à sua situação econômica. Ela está associada também ao fato de seu comportamento se constituir como algo anacrônico e externo em relação aos ritmos, às mentalidades e às atitudes habituais em uma sociedade e um contexto histórico marcados por engrenagens fortemente competitivas, nas quais a figura humana que vemos em cena parece não ter nem papel e nem lugar. A estranheza causada por seu Flor não diz respeito apenas a uma tensão entre ele e a criança Pedro, mas remete, fundamentalmente, a uma espécie de ruptura estrutural. Como disse acima, a mera presença de alguém como Seu Flor instaura um hiato na possível imagem da sociedade capitalista contemporânea como engrenagem essencialmente positiva (apesar das eventuais falhas e dificuldades), sociedade essa na qual todos teriam alguma função a desempenhar e da qual, igualmente, todos partilhariam algum usufruto, ainda que em medidas diferenciadas conforme, supostamente, o valor de suas contribuições e a eficácia de seus esforços. ${ }^{25}$

25 Jacques Rancière pensa a política como a experiência produtora de um hiato ou uma ruptura na configuração aceita e legitimada da sociedade. Por meio dessa ruptura ou desestabilização podem se redefinir a ordem do sensível, as tramas de poder, as negociações entre os grupos que detêm parcelas da voz e da 
No solo de João Artigos, o litígio pontual não só ressoa os confrontos mais cruciais da vida geopolítica planetária em nossos dias, mas explicita as ramificaçóes do estado de guerra nas relações cotidianas. É a esse campo semântico mais amplo que o conflito localizado remete. Esse eixo temático está disposto, no espetáculo, na forma de uma dramaturgia narrativizada e complexa, que finge adotar um diálogo simples com o receptor, mas recorre à perspectiva dura do litígio para tratar do tema aparentemente ameno do cotidiano de um palhaço. Mas é na focalização de uma indecisão, isto é, na colocação em questão do tema de quem é o territorista e quem é o bufão na sociedade contemporânea, tema contido já no título da peça (Homem-bom$b a)$, que se encontra o desafio intelectual e político proposto pela performance, que termina com a projeção de uma seqüência de fotos de guerras civis africanas, de crianças negras armadas para a luta, de campos de refugiados miseráveis ao lado de fotos que se referem aos Estados Unidos e ao Governo Bush.

No espetáculo de Júlio Adrião, $A$ descoberta das Américas, ${ }^{26}$ dirigido por Alessadra Vannucci, há também uma tematização intensa do litígio na sociedade planetária. O conflito agora diz respeito às guerras de conquista e colonização da América, guerras movidas pelo homem europeu do Renascimento. O solo de Adriāo nos mostra o personagem Johan, um europeu pobre que viajou para o novo mundo em uma frota de conquistadores, sendo ele um fugitivo da inquisição. Johan rememora e revive situaçôes que relata aos espectadores. Há uma grande liberdade no trato poético do tempo, permitindo que Johan, que teria vivido no século XVI, fale aos espectadores atuais. Mencionam-se, em gags de comicidade certeira, determinados aspectos da vida contemporânea, inserindo-os, inesperada e repentinamente, no episódio que está sendo relatado e que se refere à chegada do homem europeu ao chamado novo mundo. Em certo momento, por exemplo, Adrião associa, em menção breve e veloz, as crianças indígenas e as atuais, referindo-se ao hábito de assistir à televisão, como se os pequenos indígenas partilhassem da mesma prática.

Por meio da pura atividade mimética solitária de Adrião, com os meros recursos de um gestual expressivo e diversificado e de intensas variações vocais dominadas pelo ator, visualizamos Johan ao lado dos personagens individuais e no interior dos grandes grupos humanos em que se encontra a cada instante. As situações relatadas e revividas por Johan/Adrião são numerosas e bastante inusitadas, a exemplo daquela em que acompanhamos a personagem suturando índios com feridas abertas por ataques de tribos inimigas, sem que Johan dispusesse nem de técnica, nem de instrumentos e materiais necessários à tarefa. Vemos também o narrador-protagonista supostamente prever tempestades e, em decorrência de circunstâncias meramente casuais como a dessas previsóes, agora narradas e revividas, vir a ser, na ocasião em que se deram tais ocorrências, premiado com a afeição dos silvícolas e não só escapar de ser devorado

visibilidade, supostamente comum aos sujeitos que integram essa sociedade. A política seria uma atividade, momentaneamente, desidentificadora da imagem dos sujeitos e das instituições tidas por socialmente legítimas. Política e subjetivação se entrelaçam de modo complexo no pensamento desse autor, que é referência fundamental na abordagem de produtos artísticos que faço neste texto (Rancière, 1996, p. 35-71; 2005, p. 45-62).

26 O espetáculo tem texto de Dario Fo, traduzido e adaptado por Júlio Adrião e Alessandra Vannucci, que também assina a direção da peça. A iluminação é de Luiz André Alvim e o figurino de Priscila Duarte. Assisti ao trabalho em espaços distintos no ano de 2007 (Rio de Janeiro: Centro Cultural da Caixa e Teatro do Leblon) e agradeço ao ator e à diretora a cessão do registro videográfico da peça. 
em ritual de canibalismo, mas, ainda por cima, tornar-se líder de tribos indígenas contra a investida de grupos espanhóis.

Esses grupos que inicialmente o personagem desejava encontrar, para poder voltar à sua terra, serão por ele rechaçados. Cria-se, assim, uma situação na qual o europeu pobre e anônimo que é Johan será objeto de uma espécie de crise de identidade. A crise da auto-imagem e da pertinência cultural de Johan diz respeito à situação, na qual os novos elos de identificação são gerados. O que se produzirá é uma identidade fronteiriça e limítrofe. Não se trata mais da pertinência segura a qualquer campo identitário, nem àquele associado ao homem europeu e a seu horizonte cultural, nem ao universo no qual se integra de modo tenso.

No espetáculo de Júlio Adrião, a associação entre a situação encenada e as guerras imperialistas atuais não é representada de modo direto por palavras ou imagens projetadas, que não são, aliás, utilizadas em momento algum da peça. Já no solo de João Artigos, fazem-se associações da situação encenada com conflitos políticos e sociais recentes de modo explícito. No trabalho de Artigos, recorre-se, de fato, tanto a menções verbais, quanto à projeção inicial e final de imagens, para se fazer referência às tensões urbanas em uma cidade como o Rio de Janeiro, como também às guerras movidas pelo Governo americano no oriente e, ainda, aos conflitos africanos do presente. Mas mesmo que não haja a tematização direta do contexto geopolítico contemporâneo, a perspectiva da qual se recorre, no texto de Dario Fo e na performance de Júlio Adrião, às violentas guerras históricas de conquista do período renascentista, é uma perspectiva associada (no horizonte cultural dos criadores e dos receptores contemporâneos) ao atual quadro de guerra permanente. ${ }^{27}$

\section{V}

O espetáculo de Júlio Adrião revela certo pressuposto de pureza, enfatizando e valorizando uma idéia de especificidade do teatro como meio expressivo. $\mathrm{O}$ trabalho não conta com qualquer elemento cenográfico, exceto uma rede de algodão em que o ator se deita ao final da sua exibição. O desenho de luz é também muito simples. Não há utilização de cor, nem recortes espaciais por meio de planos muito marcados de incidência da luz. A iluminação é predominantemente aberta e recorre basicamente a mudanças de intensidade. Há pontos de contato significativos entre os espetáculos de Adrião e de Márcio Libar em termos de despojamento de recursos cênicos, mas principalmente no que tange ao registro de ator, especialmente considerando a primeira parte de $O$ pregoeiro, trecho no qual Libar ainda não se apresenta como o palhaço Cuti-Cuti.

As performances dos dois atores (a de Adrião, por um lado, e a de Libar na primeira metade de seu espetáculo $O$ pregoeiro, por outro) lembram igualmente exibições de artistas anônimos e populares das ruas de grandes cidades. Ambos os atores tiveram experiência com esse tipo de trabalho, puderam observar esse universo de palhaçaria de rua, que toca, em certos aspectos, a performance dos vendedores ambulantes, e lida com uma graça instantânea direcionada aos passantes cuja atenção não é garantida e se necessita atrair. A rapidez do jogo, o recurso ao cotidiano, a ironia direta, a malícia das falas de duplo sentido, a agilidade verbal são alguns dos elementos provenientes desse tipo de exibição popular introduzidos nos trabalhos performáticos de Libar e de Adrião. Trabalhos esses nos quais os dois artistas sintetizam diferentes aspectos da sua criação atoral: consciên-

27 Para Antônio Negri e Michael Hardt, as forças dominantes dependem de uma espécie de estado permanente de guerra nos dias atuais, para a manutenção de suas posiçōes de hegemonia global, conforme a análise desses autores sobre o poder (biopoder) e os modos possíveis de resistência (bioprodução) na contemporaneidade (Hardt \& Negri, 2005). 
cia e domínio técnico apurados em treinamentos corporais específicos (o circo, o clown etc.), teatralidade popular não dramática associada a modos sofisticados de depuração e de organização do material empregado (relato de ocorrências pontuais, sonoridades vocais e percursivas feitas com o uso do próprio corpo, gags cômicas, habilidades corporais etc.).

Entre o espetáculo de Libar e o de João Artigos também há muitos pontos de contato, decorrentes da experiência compartilhada ao longo de anos de trabalho comum no Teatro de Anônimo, grupo ao qual pertenceu Libar e do qual foi um dos fundadores ao lado de Artigos, tendo se afastado da trupe para se dedicar a um trabalho individual há poucos anos. Tanto Libar, quanto Artigos fazem brincadeira com o fato de que os efeitos cênicos de que se utilizam (confetes e serpentinas no caso de Libar, do mesmo modo que o "cachorrinho acrobata" no espetáculo de Artigos) são comprados no comércio popular e barato do centro do Rio de Janeiro ou de São Paulo, conforme explicitam os dois artistas em suas exibições. Com esse tipo de procedimento se opera o rebaixamento de qualquer concepção sacralizadora do teatro e do trabalho do ator, ou de técnicas determinadas de que ele se utilize. No espetáculo de Artigos, o cachorrinho acrobata, chamado Iorick, é incendiado a cada espetáculo e, em momento posterior da peça, ele é segurado pelo personagem Seu Flor que, no auge da tensão com o menino Pedro, se dirige ao boneco (o cachorrinho de pelúcia) carbonizado e fala para ele o famoso monólogo de Hamlet do ser ou não ser, expressão do dilema entre agir ou não agir, tornar-se ou não sujeito. Na peça de Artigos, a caveira de Iorick - que é o cachorrinho de pelúcia barato carbonizado - funciona também como elemento burlesco de rebaixamento das referências literárias canonizadas, como a do conhecido monólogo do Hamlet.
No espetáculo de Artigos, os bonecos que representam o menino Pedro e seus colegas, a voz gravada que se atribui a eles em certos momentos, ${ }^{28} \mathrm{o}$ vídeo e a projeção de fotografias aos quais se recorre pressupõem uma concepção de teatralidade diferente daquela que se expressa no trabalho estritamente corporal e vocal com que Julio Adrião, concretiza seu leque de personagens. O espetáculo de Adrião poderia se associar a uma série de outros trabalhos teatrais recentes nos quais se parece enfatizar um conceito da natureza própria do teatro como pertinente, fundamentalmente, à relação do ator com os espectadores, no momento em que se dá seu encontro. Freqüentemente essa concepção teatral se associa à rejeição e à depreciação de elementos não atorais (trilha gravada, tecnologias de som e da imagem etc.), em decorrência de esses elementos serem entendidos, então, como meros adornos ou aditivos associados a uma espetacularização supostamente falsa, ou diretamente ligada à sociedade da mídia. $\mathrm{O}$ modo de Artigos criticar a sociedade contemporânea não se produz como afirmação de uma pureza ou legitimidade teatral proveniente da exclusão de elementos ou de mídias externas ao domínio tradicionalmente atoral.

O espetáculo de João Artigos tem uma estrutura que se explicita como monólogo narrativo dramaturgicamente formalizado. Os próprios elementos cênicos mobilizados por Artigos (os bonecos rígidos e perfilados ao fundo, o fino tecido transparente que pende do teto e os separa de uma área frontal de atuação, o trânsito do ator entre as áreas de trás e da frente, a projeção de imagens na parede de fundo, a utilização de voz gravada etc.) pressupóem um espaço fechado. Do mesmo modo que a interação do ator com as vozes gravadas (que representam as crianças e o menino Pedro) e o desenho dramático-narrativo de uma tensão crescente entre Seu Flor e seu antagonista são aspectos que pres-

28 O áudio das crianças, conforme o programa é feito por Flora Pereira, Matheus Viana, Miguel Adriāo e Willian Souza. 
supõem mais uma organização dramatúrgica prévia do que um desenvolvimento que se faça no calor da hora. O prévio arranjo dramatúrgico-composicional da performance é também pressuposto pela conjugação complexa de informaçôes veiculadas por fontes muito diversificadas: as imagens projetadas, o som gravado, as falas do ator, os vários elementos de figurinos utilizados, as três malas, o teatrinho de animação que se faz na cena do "Igor - o exterminador" de palhaços, os liquidificadores acionados em certo momento da peça, ligados a fios elétricos que tombam do alto da sala.

A atuação de Libar se explicita como exibição mais aberta e despojada em termos de composição do que a de Adriāo, cuja performance é mais detalhada e ritmicamente mais controlada pelo ator. Libar parece permitir espaços de respiração nos quais as intervenções do acaso e do momento são mais absorvidas. Essa sensação é decorrente em parte do fato de Libar se dirigir inúmeras vezes aos espectadores, de solicitar sua participação (dando-lhes, por exemplo, confetes e serpentinas a serem jogados sobre o ator em representação burlesca do endeusamento do artista), de transitar em meio ao público tanto na primeira fase do trabalho (etapa da atitude mais reggae e urbana), quanto no momento posterior (longo quadro lírico do doce palhaço Cuti-cuti).

Essa relação tão direta e intensa de Libar com os espectadores exige uma modulação rítmica mais distendida, para que se viabilize o perfeito aproveitamento das pulsações provenientes da sala, inteiramente iluminada, propiciando-se também uma interação dos receptores entre si. É claro que esse ritmo distendido e pouco controlado depende também de um grande domínio da duração por parte do artista, que se mantém na condução dos instrumentos que ativam e, sub-repticiamente, orientam o curso dessa respiração aparentemente livre do coletivo na sala. Essa relação mais aberta com a platéia estabelece um diferencial nítido com o espetáculo de Júlio Adrião. Em $A$ descoberta das Américas, o ator se dirige ao público, estando sempre ele no palco, e dominando um intenso fluxo vocal (não só lingüístico-verbal, mas também sonoro, musical, onomaitopaico), acompanhado de uma atividade corporal e mimética ininterrupta, de grande criatividade e capacidade de captação concentradora e direcionadora da atenção dos receptores. O improvisador de rua a que se faz referência no espetáculo de Adrião é ansioso no preenchimento do tempo e se relaciona ficcionalmente com a figura do personagem Johan, que é mostrado como estando sempre em apuros e urgências inauditas (na fuga de perseguidores diversos na Europa e na América, na iminência de ser devorado em ritual antropofágico etc.). No caso de Libar, o ritmo mais ameno se associa com outras referências: o reggae, o molejo de corpo do malandro carioca, uma atitude não aderente às urgências da fuga ou da conquista, assemelháveis àquelas em que flagramos o europeu Johan.

No espetáculo de Márcio Libar, não se configura um conflito de classes, conforme o que se vê no trabalho de Artigos por meio da relação entre seu Flor e o menino Pedro representada pelo ator. A performance de Libar, podese dizer, distancia-se mais radicalmente, que a de Artigos, do modelo dramático de um conflito intersubjetivo. Esse modelo é pressuposto em Homem-bomba, ainda que, o espetáculo não o instaure sob uma forma ortodoxa. Trata-se, ao contrário, de um solo, da narrativa de um evento passado, com grande parte do texto veiculado diretamente para os espectadores e um dos pólos do conflito intersubjetivo representado por bonecos. Esses aspectos afastam, é claro, o espetáculo de João Artigos da forma pura e fechada do drama tradicional. Mas, no caso de Libar, ainda que não se utilize de qualquer menção ao modelo de conflito dramático intersubjetivo (modelo esse que subjaz como referência na performance narrativizada de Artigos), a própria presença de Libar e o jogo irônico que o artista estabelece na sua relação com os espectadores estão carregados de uma tensão interna, que re-introduz, de maneira problemática, uma dramaticidade (em sentido amplo, como crise e 
divisão). Trata-se, na verdade, de uma jocosidade ambivalente e desestabilizadora de qualquer imagem harmônica da interação social.

Para artistas como Júlio Adrião, João Artigos e Mácio Libar, o circo, o palhaço e a rua são referências evidentes, mesmo nos solos em que se apresentam no circuito regular de teatro, como no caso dos trabalhos aqui discutidos. A referência a uma teatralidade popular, e despojada em termos formais, é significativa também, ainda que diferentemente, nos espetáculos de Clarice Niskier e de Pedro Cardoso. Os prólogos dos dois trabalhos mostram os artistas comentando os processos de criação dos espetáculos, instaurando uma relação supostamente dessacralizada e cotidiana com os espectadores, relação na qual são feitos comentários sobre o teatro, sobre o que está acontecendo no dia da apresentação, sobre a entrada dos últimos espectadores antes do início do espetáculo propriamente dito, enquanto se dá aquela espécie de conversa prévia.

Nos prólogos dos solos de Niskier e Cardoso, a luz está inteiramente aberta, a sala iluminada e os atores desprovidos de qualquer composição de personagem ou de qualquer formalização nítida dos gestos e movimentos. Os dois trabalhos tiveram participação de Amir Haddad nas concepções dos espetáculos e esses elementos de despojamento são visivelmente associados às pesquisas e interesses artísticos próprios de Amir. Certo aspecto de desconstrução da representação e do histrionismo, por exemplo, está presente há muitos anos nas investigações teatrais de Amir e não só em sua trupe atual, o Grupo Ta na Rua, mas também em seus grupos anteriores e em trabalhos que dirige a convite de atores no circuito comercial, a exemplo das peças de Niskier e Cardoso.

Amir Haddad é homenageado em citação breve que aparece em certo momento do espetáculo de Libar. $\mathrm{O}$ artista, que foi um dos criadores do Teatro Oficina no final dos anos 50 ao lado de Zé Celso Martinez Corrêa, é - em seu conhecido interesse pela teatralidade da rua, pela palhaçaria popular e pela atuação despoja- da e desestabilizadora dos formatos institucionalizados de teatro - uma referência importante também para compreensão de trabalhos como os de Júlio Adrião e de João Artigos, dentre outros, no contexto da produção cênica atual do Rio de Janeiro, em grande medida pela amplitude da ação político-teatral do Grupo Tá na Rua, liderado por Amir.

Em certo momento de $O$ autofalante, a personagem tensa levada à cena por Pedro Cardoso reclama que televisão só fala e não ouve, que televisão não tem orelha. Também se irrita com a "musiquinha" (como diz) que lhe é imposta aos ouvidos enquanto espera longamente pelo tele-atendimento de uma central de telefonia celular. No espetáculo $O$ homem bomba, testemunhamos também a extorsão da voz e do discurso do Seu Flor pelo menino Pedro, que pretende não apenas humilhá-lo, mas também calar-lhe. Já a personagem que ouvimos em $O$ animal do tempo fala em moto contínuo, mas é para ninguém, uma vez que, em sua solidão, não se configuram interlocutores. Estão todos mortos no cemitério em que vagueia. Em muitos dos espetáculos solos recentemente exibidos no Rio de Janeiro, o que está em foco são, em grande medida, as partilhas estabelecidas no sensível quanto a quem pode ter acesso à fala, quanto a quem merece ser ouvido, a quem se concede essa possibilidade na sociedade contemporânea. $\mathrm{O}$ poder é discutido por meio do cotidiano e da reflexão sobre a identidade, entendida, em muitos dos trabalhos, de forma móvel, em conexão com as posições adotadas pelos sujeitos, e não por qualquer viés essencialista tradicional. A atitude política, nos trabalhos solos recentes que atingem maior força e radicalidade, configura-se, fundamentalmente, como agenciamento de modos de subjetivação transformadores em relação às formas hegemônicas de produção de identidade coletiva e individual nas sociedades contemporâneas. Formas hegemônicas essas associadas em grande medida aos diversos modos de organização discursiva e imagética próprios aos meios de comunicação de massa. Também se expressa, nos 
espetáculos, uma tendência predominantemente não formalista e não substancialista na visão do teatro e do trabalho do ator. O projeto solo responde freqüentemente a uma necessidade de tomada de posição do ator frente à linguagem teatral e às concepçôes de teatralidade vigentes. Mas, a fala frontal e direta dos solos teatrais mostra-se como problematizadora, em níveis diversos e intensidades variadas, da própria idéia de comunicação direta e frontal.

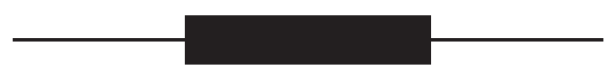

\section{Referências bibliográficas}

BAUDRILLARD, Jean. Simulacros e simulaçôes. Trad. de Maria João da costa Pereira. Lisboa: Relógio d'Água, 1991.

BENJAMIN, Walter. Obras escolbidas. Vol. 1: "Magia te técnica, arte e política - Ensaios sobre literatura e história da cultura”. Trad. de Sérgio Paulo Rouanet. São Paulo: Brasiliense, 1987.

CERTEAU, Michel de. A invenção do cotidiano: 1. artes do fazer. Trad. de Ephraim Ferreira Alves. Petrópolis: Vozes, 1994.

DEBORD, Guy. A sociedade do espetáculo. Trad. de Estela dos Santos Abreu. Rio de Janeiro: Contraponto, 1997.

DELEUZE, Gilles. A imagem-tempo. Trad. de Eloísa de Araújo Ribeiro. São Paulo: Brasiliense, 2005.

. Conversaçôes, 1972-1990. Trad. de Peter Pál Pelbart. Rio de Janeiro: Ed 34,1992.

HARDT, Michael \& NEGRI, Antonio. Multidão. Trad. de Clóvis Marques. Rio de Janeiro: Record, 2005.

HOLLANDA, Heloisa Buarque de. Impressōes de viagem: CPC, vanguarda e desbunde: 1960-1970. Rio de Janeiro: Aeroplano, 2004.

JAMESON, Fredric. Pós-modernismo: a lógica cultural do capitalismo tardio. Trad. de Maria Elisa Cevasco. São Paulo: Ática, 1996.

NOVARINA, Valère. Discurso aos animais (O animal do tempo e a inquietude). Trad. de Ângela Leite Lopes. Rio de Janeiro: 7 Letras, 2007.

ORTIZ, Renato. Cultura brasileira e identidade nacional. São Paulo: Brasiliense, 1994.

RANCIÈRE, Jacques. O DESENTENDIMENTO - política e filosofia. Trad Angela Leite Lopes. São Paulo: Ed 34, 1996.

RANCIÈRE, Jacques. A partilha do sensivel: estética e politica. Trad. de Mônica Costa Netto. São Paulo: EXO experimental/Editora 34, 2005. 